\title{
Identification of Arterial and Venous Segments of Blood Vessels Using Alkaline Phosphatase Staining of Ink/Gelatin Injected Tissues
}

\author{
Tatsuo UshIKI ${ }^{1}$ and Kazuhiro $\mathbf{A B E}^{2}$ \\ Department of Anatomy ${ }^{1}$, Niigata University School of Medicine, Niigata; and Department of Anatomy, Hokkaido University \\ School of Medicine ${ }^{2}$, Sapporo, Japan
}

Received April 6, 1998

Summary. The present study describes a method for discriminating between the arterial and venous segments of blood vessels in mouse tissues and organs using alkaline phosphatase (ALPase) staining of ink/gelatin injected tissues.

Anesthetized mice were injected through the left ventricle with blue ink/gelatin, and various organs and tissues were removed from the body and fixed by immersion in $10 \%$ formalin. Sections $50-100 \mu \mathrm{m}$ thick were incubated for ALPase in a medium containing naphthol AS-BI phosphate and fast red TR by the azocoupling method. In such specimens as the brain and skeletal muscles, ALPase activity was found in arterioles and capillaries on the arterial side, whereas it was absent in capillaries on the venous side and in venules. In the liver, only branches of the hepatic artery were positive. ALPase activity was absent in the vessels of the lung except for a positive reaction in branches of the bronchial arteries. These findings indicate that the ALPase activity is confined to the arterioles and arterial segments of the capillaries in the systemic circuit. Thus, ALPase staining of ink/gelatin injected specimens is a useful method for differentiating the arterial and venous segments of the micro-vascular bed in various organs and tissues in mice.

A number of techniques have been used to study the microvascular bed in various tissues and organs. Two related techniques have been classically applied to study the organization of the microvascular system: light microscopy of dye injected and cleared tissue specimens (e. g., FuJiTA, 1973; AKIMA et al., 1987), and scanning electron microscopy of plastic injected corrosion casts (MURAKAMI, 1971; OHTANI and MURAKAMI, 1992). These methods are indeed effective for visualizing the three-dimensional organization of the microvascular bed, but discrimination between the arterial and venous segments of the microvessels is often difficult. To overcome this problem, we recently developed a new, convenient method that allows one to distinguish arterial and venous components clearly by light microscopy. The basis for this technique is the localization of alkaline phosphatase (ALPase) in the arterial segments of ink injected vessels. The present study enumerates the procedures of this method, and then presents some results attesting to its efficacy in the observation of the microvascular bed in various tissues and organs.

\section{MATERIALS AND METHODS}

Young adult (4-6 weeks) dd-mice of both sexes were used in the present study. The mice, anesthetized with diethyl ether, were perfused through the left ventricle with physiological saline containing heparin $\left(10^{4} \mathrm{IU} / \mathrm{l}\right)$ and $0.1 \%$ lidocaine at $37^{\circ} \mathrm{C}$ and then with an injecting medium consisting of 1:10 diluted blue ink (Rotring-Werke Riepe KG, Germany), 2\% gelatin, heparin $\left(10^{4} \mathrm{IU} / \mathrm{l}\right)$ and $0.1 \%$ lidocaine. Parts of the brain, tongue, thymus, heart, mesenteric lymph nodes, stomach, small intestine, liver, pancreas, kidney and soleus muscle were then removed and immersed in $4 \%$ paraformaldehyde in $0.1 \mathrm{M}$ phosphate buffer ( $\mathrm{pH} 7.4$ ) at $4^{\circ} \mathrm{C}$ for $2-4 \mathrm{~h}$. After being washed in the buffer solution, some specimens were directly cut on a microslicer (Dosaka EM, Japan) at $80-100 \mu \mathrm{m}$ in thickness, while others were immersed in $30 \%$ sucrose overnight at $4^{\circ} \mathrm{C}$ and cut either on a cryomicrotome at a $100 \mu \mathrm{m}$ thickness or on a cryostat at about $10 \mu \mathrm{m}$. The sections were incubated in the reaction medium for ALPase activity according to the azo-dye method (BURSTONE, 1962; STOWARD and 

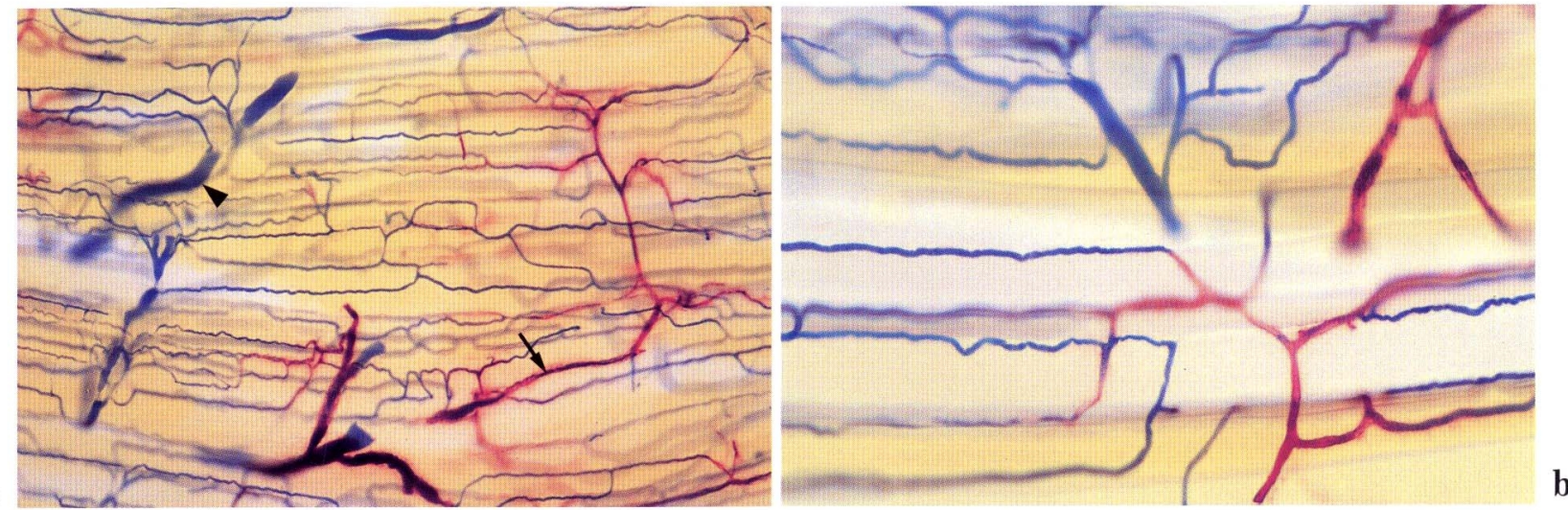

Fig. 1. Blue ink/gelatin injected tissue sections of the mouse skeletal muscle (soleus muscle) reacting for ALPase. a. A low-power micrograph of a longitudinal section. Arterioles (arrow) are stained red with the strong reaction of their walls to ALPase, while venules (arrowhead) remain blue. b. A closer view showing a transition from arterial (red) to venous (blue) segments of capillaries.
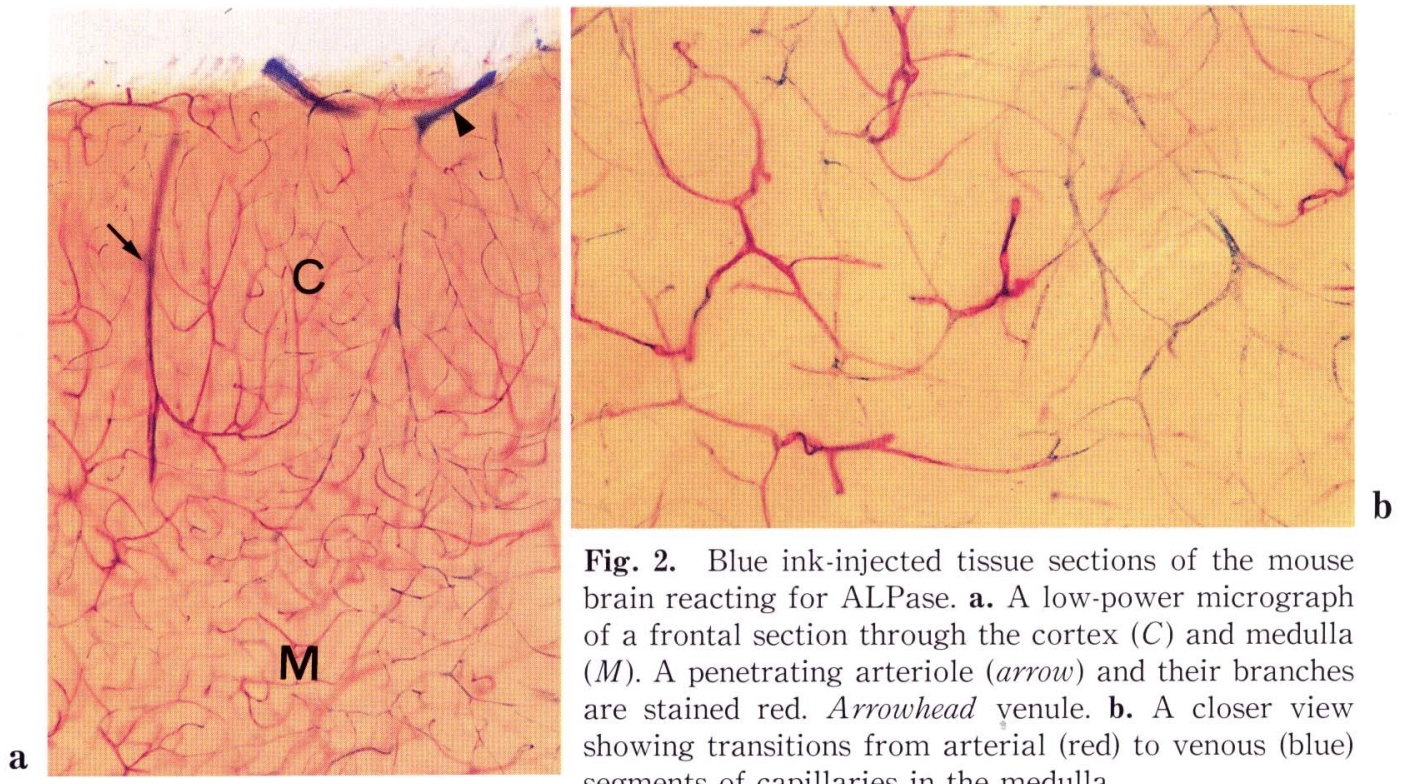

Fig. 2. Blue ink-injected tissue sections of the mouse brain reacting for ALPase. a. A low-power micrograph of a frontal section through the cortex $(C)$ and medulla $(M)$. A penetrating arteriole (arrow) and their branches are stained red. Arrowhead venule. b. A closer view showing transitions from arterial (red) to venous (blue) segments of capillaries in the medulla.

PEARSE, 1991); the medium contained $40 \mathrm{mg}$ of naphthol AS-BI phosphate (Sigma Chemical Co.) dissolved in $0.25 \mathrm{ml}$ of $\mathrm{NN}^{\prime}$-dimethylformamide and $30 \mathrm{mg}$ of fast red TR salt (Sigma Chemical Co.) dissolved in 50 $\mathrm{ml}$ of $0.1 \mathrm{M}$ Tris- $\mathrm{HCl}$ buffer ( $\mathrm{pH} 9.2$ ). The sections were incubated in this medium for 20-60 min at room temperature, rinsed with distilled water and then mounted in glycerin or glycerin-gelatin. Control sections were incubated in a substrate-free medium.

\section{RESULTS}

In ink-injected specimens, blood vessels were clearly observable due to the presence of blue ink in the lumen. The localization of the ALPase activity was not changed irrespective of the incubation time, although the longer incubation produced increased reactivity of the vessels.

In skeletal muscles, ALPase activity was present in intramuscular arteries to capillaries on the arterial side, but was absent in capillaries on the venous side 

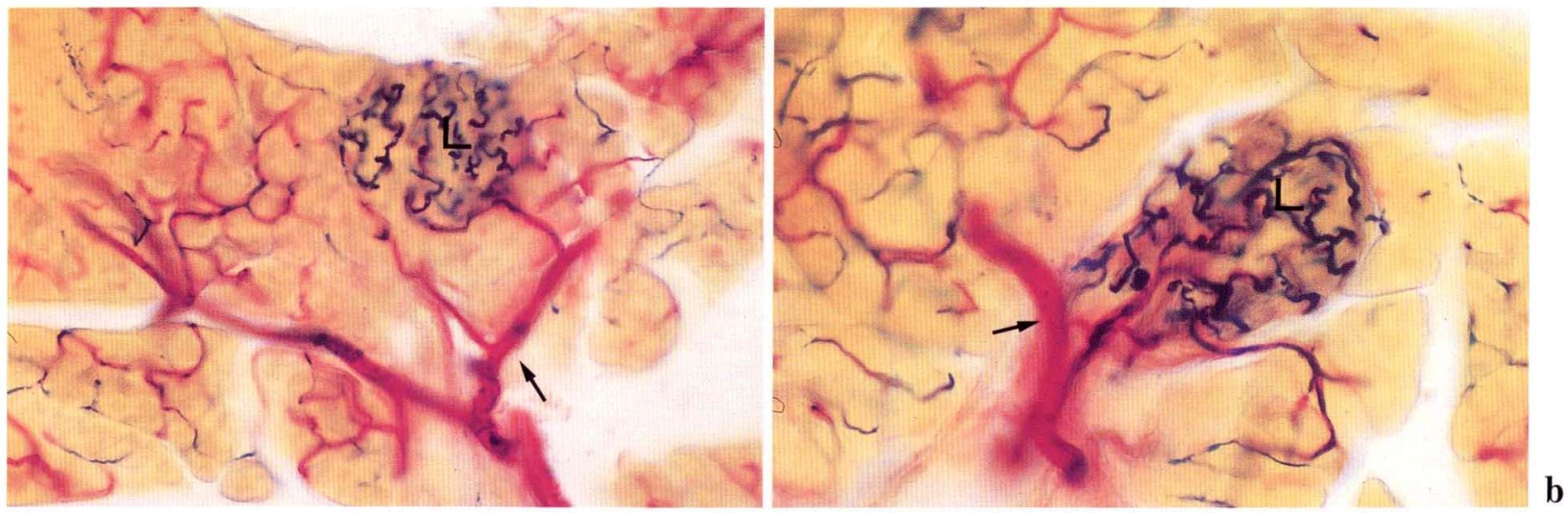

Fig. 3. Blue ink-injected tissue sections of the mouse pancreas reacting for ALPase. a and b. Arterioles (arrows) and their branches are stained red, while sinusoidal capillaries $(L)$ in the islet of Langerhans, as well as capillaries of venous side in the acini, are blue.
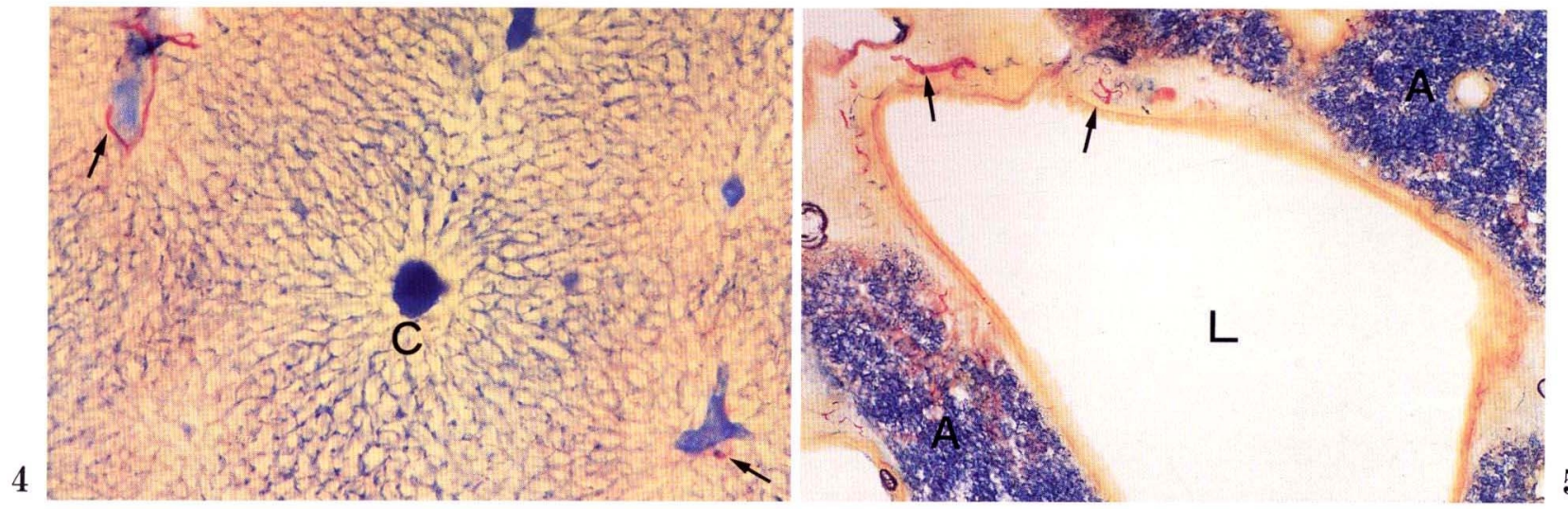

Fig. 4. A blue ink-injected tissue section of the mouse liver reacting for ALPase. Only branches of the hepatic artery (arrows) are positive (stained red) for ALPase activity. $C$ central vein.

Fig. 5. Blue ink-injected tissue section of the lung reacting for ALPase. ALPase activity is restricted to branches of the bronchial artery (arrows). L lumen of a bronchus.

and in venules (Fig. la). Thus the arterial portion of the microvessels was stained red, while their venous portion remained blue. In thin sections ALPase reaction was localized in the endothelia of the vessels. The transition from red to blue portions could readily be followed in longitudinally hit capillaries (Fig. 1b). In the brain, ALPase activity was found from cortical branches of the cerebral arteries to arterial segments of capillaries (Fig. 2a, b). Venous segments of the capillaries and venules were, however, negative for the ALPase activity.

In the pancreas, the activity was also present from interlobular arteries but was strongest in intralobular arterioles (Fig. 3a, b). In the acinar branches of the intralobular arterioles, the activity became weak toward the capillaries and was absent in the venous segments of the capillaries. The afferent vessels of islets also showed a strong reactivity for ALPase; after reaching an islet, they divided into dilated sinusoidal capillaries, where the ALPase reactivity was faint or absent. The efferent vessels radiating from islets were usually negative for ALPase activity, although some efferent vessels near the afferent vessels, were weakly reactive.

In the small intestine, ALPase activity was found in the submucosal arteries and mucosal arterioles, but was weak or absent in the villous capillary networks (micrograph not demonstrated).

In the liver, branches of the hepatic artery were positive for ALPase activity, whereas branches of the 
portal veins, sinusoids and central veins were all negative (Fig. 4).

ALPase activity was absent in all pulmonary arterial and venous vessels except for a positive reaction in branches of the bronchial arteries (Fig. 5).

In the kidney, ALPase activity was present in intralobular arteries. Afferent and efferent vessels and renal glomeruli were also faintly positive (micrograph not demonstrated).

Data on the localization of ALPase staining reactions of blood vessels in the mouse tissues tested are summarized in Table 1.

\section{DISCUSSION}

The present study has indicated that ALPase activity is confined to arterioles and arterial segments of capillaries in the systemic vascular circuit of the mouse; ALPase activity is not detected in the venous segments of the systemic circuit nor in vessels of the pulmonary circuit.

ALPase activity has often been believed to be present in most capillaries (e. g., JózSA et al., 1985; SVENSSON et al., 1988 ). On the other hand, some investigators have noted that ALPase activity is negative in certain segments of capillaries (e. g.,
WERNER et al., 1987). In his histochemical studies of rats and mini-pigs, LOJDA (1979) first correctly pointed out that the ALPase only depicts the arterial part of capillaries as well as arterioles. Some later investigators have also confirmed the localization of the ALPase activity on the arterial part of the vessels in such tissues as skeleta1 muscles (MrAZKOVÁ et al., 1986; GRIM and CARLSON, 1990), cardiac muscles (SchulTz-Hector et al., 1993; Koyama et al. 1997) and brain (RowAN and MAXWELL, 1981) in different animals. The present study has clarified more systematically than before that the ALPase activity is restricted to the arterial segments of capillaries but absent in the venous portion of the capillaries in the systemic vascular circuit of the mouse. Thus, these findings indicate a possible underestimation of the density of capillaries by looking at tissue sections reacting for ALPase.

It is still unelucidated why ALPase activity is restricted to the arterial part of small vessels in the systemic vascular circuit. SCHULTZ-HECTOR et al. (1993) suggested a transendothelial porter function for ALPase in the endothelial cells, since ALPase activity was localized to pinocytotic vesicles as well as endothelial plasma membrane. They also introduced other possible functional roles for ALPase such as an inhibitor of platelet aggregation (HATMI et

Table 1. Alkaline phosphatase localization of blood vessels in the mouse

\begin{tabular}{|c|c|c|c|c|}
\hline & \multirow{2}{*}{$\begin{array}{c}\text { Arterioles } \\
\text { (arteries) }\end{array}$} & \multicolumn{2}{|c|}{ Capillaries } & \multirow{2}{*}{$\begin{array}{l}\text { Venules } \\
\text { (veins) }\end{array}$} \\
\hline & & Arterial & Venous & \\
\hline Skeletal muscles & ++ & + & - & - \\
\hline $\begin{array}{l}\text { Heart } \\
\text { (Cardiac muscle) }\end{array}$ & ++ & + & - & - \\
\hline Brain & ++ & + & - & - \\
\hline Pancreas & ++ & + & - & - \\
\hline Small intestine & ++ & + & - & - \\
\hline Tongue & ++ & + & - & - \\
\hline Lymph node & ++ & + & - & $\stackrel{-}{\text { (High endothelial venules) }}$ \\
\hline Liver & $\begin{array}{c}++ \\
\text { (Hepatic arterioles) }\end{array}$ & & (Sinusoid) & $\begin{array}{c}- \\
\text { (Portal venules) } \\
\text { (Central veins) }\end{array}$ \\
\hline Lung & $\begin{array}{c}++ \\
\text { (Bronchial arterioles) } \\
- \\
\text { (Pulmonary arterioles) }\end{array}$ & & - & - \\
\hline Kidney & ++ & $\begin{array}{l}+ \\
(+ \text { Glor }\end{array}$ & $\begin{array}{c}- \\
\text { oillaries) }\end{array}$ & - \\
\hline
\end{tabular}


al., 1991) and a regulator of endothelial cell proliferation (LINDNER et al., 1998).

In the present study, we have also shown that the ALPase staining of ink-injected specimens is a useful method for discriminating the arterial and venous segments of microvascular bed. Some investigators (MrazKOVÁ et al., 1986; GRIM and CARLSON, 1990) succeeded in distinguishing between arterial and venous portions of capillaries in rat skeletal muscles using a combined ALPase and dipeptidylpeptidase IV (DPP IV) staining. However, DPP IV activity is negative in the mouse blood vessels (GRIM and CARLSON, 1990). In addition, the preservation of DPP IV activity is somewhat difficult: for example, tissue sections cut on a cryostat must be fixed with chloroform-acetone (LOJDA, 1979). In contrast, ALPase activity is well preserved in aldehyde fixed tissues, and its localization in arterial vessels is consistent across various species (GRIM and CARLSON, 1990). Thus, ALPase staining of the ink-injected specimens as described in the present study will be useful for histological studies of the microvascular bed in various organs and tissues of mice, and possibly in other mammals.

Acknowledgments. We thank Prof. B. L. MunGER for his valuable discussions.

\section{REFERENCES}

Akima, M., H. Nonaka, M. Kagesawa and K. Tanaka: A study of the microvasculature of the cerebellar cortex. The fundamental architecture and its senile change in the cerebellar hemisphere. Acta Neuropathol. 75: 6976 (1987).

Burstone, M. S.: Histochemical demonstration of phosphatases in frozen sections with naphthol AS-phosphates. J. Histochem. Cytochem. 9: 146-153 (1961).

FuJITA, T.: Insulo-acinar portal system in the horse pancreas. Arch. Histol. Jap. 35: 161-171 (1973).

Grim, M. and B. M. CARLson: Alkaline phosphatase and dipeptidylpeptidase IV staining of tissue components of skeletal muscle: a comparative study. J. Histochem. Cytochem. 38: 1907-1912 (1990).

Hatmi, M., B. HaYe, J. M. Gavaret, B. B. Vargaftig and C. JACQUemin: Alkaline phosphatase prevents platelet stimulation by thromboxane-mimetics. Brit. J. Pharmacol. 104: 554-558 (1991).

Józsa, L., A. Réffy, Z. Demel and J. B. BÁlint : Analysis of skeletal muscle capillarization: methodological problems. Acta Physiol. Hungar. 66: 161-168(1985).

Koyama, T., M. GaO, T. Ueda, S. Batra, K. ITOH, T. USHIKI and K. ABE: Different enzyme activities in coronary capillary endothelial cells. Adv. Exper. Med. Biol. 411: 359-364 (1997).
Lindner, H., U. Behrends, Y. Misumi, E. Kremmer, G. EISSNER and S. Schultz-Hector: Loss of myocardial capillary endothelial-cell alkaline phosphatase (ALP) activity in primary endothelial cell culture. Cell Tiss. Res. 291: 497-505 (1998).

LoJDA, Z.: Studies on dipeptidyl (amino) peptidase IV (glycyl-proline naphthylamidase) II. Blood vessels. Histochemistry 59: 153-166 (1979).

Mrazková, O. M. Grim and B. M. Carlson: Enzymatic heterogeneity of the capillary bed of rat skeletal muscles. Amer. J. Anat. 177: 141-148 (1986).

Murakami, T.: Application of the scanning electron microscope to the study of the fine distribution of the blood vessels. Arch. Histol. Jap. 32: 445-454 (1971).

Ohtani, O. and T. Murakami: Routine methods for vascular casting and SEM. In: (ed. by) P. M. MotTA, T. MurakAmi and T. Fujita: Scanning electron microscopy of vascular casts: Methods and applications. Kluwer Academic Publishers, Boston-Dordrecht-London, 1992 (p. 13-25).

Schultz-Hector, S., K. Balz, M. Böhm, Y. Ikehara and L. RIEKE: Cellular localization of endothelial alkaline phosphatase reaction product and enzyme protein in the myocardium. J. Histochem. Cytochem. 41: 18131821 (1993).

Stoward, P. J. and A. G. E. Pearse: Histochemistry. 4 th ed., Vol. III. Churchill Livingstone, EdinburghLondon-Melbourne-New York-Tokyo, 1991.

Svensson, A. M., L. Jansson and C. Hellerstrom: The volume and area of the cap: llaries in the endocrine and exocrine pancreas of the rat. Histochemistry 90: 43-46 (1988).

Werner, J., M. Schünke and B. Tillmann: Histochemical visualization of lymphatic capillaries in the rat: a comparison of methods demonstrated at the posterior pharyngeal surface. Arch. Histol. Jap. 50: 505-514 (1987).

\author{
Prof. Tatsuo UsHikI \\ Department of Anatomy \\ Niigata University School of Medicine \\ Asahimachi-dori, Niigata \\ 951-8510 Japan \\ 牛木 辰男 \\ 951-8510 \\ 新潟市旭町通 1 \\ 新潟大学医学部 \\ 第三解剖学教室 \\ Tel.: +81-25-227-2058 \\ Fax: +81-25-224-1767 \\ E-mail: t-ushiki@ med.niigata-u.ac.jp
}

